\title{
Activities and Resources in Online Learning: From a Critical Thinking View
}

\author{
Danielle Morin \\ Concordia University, John \\ Molson School of Business, \\ Montreal, Quebec, Canada \\ dmorin@jmsb.concordia.ca
}

\author{
Jennifer D. E. Thomas \\ Pace University, Ivan \\ Seidenberg School of CSIS, \\ New York, NY, USA \\ jthomas@pace.edu
}

\section{Raafat George Saadé \\ Concordia University, John Molson School of Business, Montreal, Quebec, Canada}

rsaade@imsb.concordia.ca

\begin{abstract}
This article investigates the relationship between Web-based learning and Critical thinking (CT) in a web-based course on the fundamentals of Information Technology at a university in Montreal, Canada. In particular, it will identify what part(s) of the course and to what extent, critical thinking is perceived to occur. The course contains two categories of learning modules namely resources and interactive activity components. The study aimed at answering the following questions: (1) What is the effect of the learning modules on Critical Thinking? and (2) What is the relative contribution of the various learning modules on Critical Thinking skills requirements?
\end{abstract}

Keywords: Critical Thinking, Online Learning

\section{Background}

It is widely accepted that for students to perform well in the future careers, they must acquire skills and absorb knowledge efficiently and effectively. The acquisition, understanding, and use of knowledge require various learning strategies, meta-cognitive skills and the desire to use them. Critical thinking is a key skill that individuals need in order to succeed (Johnson et al., 2010). In our information society today, critical thinking is regarded as the most important skill in order to discern false, incomplete, obsolete, etc. information. The Internet has become the open medium to

Material published as part of this publication, either on-line or in print, is copyrighted by the Informing Science Institute.

Permission to make digital or paper copy of part or all of these works for personal or classroom use is granted without fee provided that the copies are not made or distributed for profit or commercial advantage AND that copies 1) bear this notice in full and 2) give the full citation on the first page. It is permissible to abstract these works so long as credit is given. To copy in all other cases or to republish or to post on a server or to redistribute to lists requires specific permission and payment of a fee. Contact Publisher@InformingScience.org to request redistribution permission. hold all types of information. While our understanding of critical thinking has improved significantly in the last two decades, a range of views about its complex structure and many areas of uncertainty and disagreements still remain. Yang (2007) provides a good perspective on those issues between cognitive scientists, educational researchers and philosophers. The body of knowledge is relatively small and limited in context and most of CT types of studies 
is related to elementary and high school education excluding the context of IT usage and CT (Marin \& Halpern, 2011).

There are several definitions of critical thinking (and instruments for its measurement), but there seems to be some common grounds around the ideas of analysis, evaluation, inference, and interpretation of CT. Follman et al., (1997) provides a comprehensive list and associated discussion. In our study presented in this article, we define critical thinking around this simpler construct as follows: "critical thinking is the process of analysis, evaluation, inference, and interpretation of resources and activities (gathered via online experiences with course material).” Students were asked to identify the extent to which they felt various activities, resources and technologies (Thomas, 2001), were perceived to support their acquisition of these skills so defined, in an entirely virtual, online course.

Considering the scarce body of research work on CT in virtual learning environments, this study provides two significant contributions: (1) At a macro level, obtain some understanding on CT in the online learning context (higher education), and (2) At a micro level, identify the kinds of resources and activities that fosters/require CT skills. With this knowledge, practitioners (teachers and online courses designers) can design and implement better online (web-based) courses by integrating learning tools to foster the development of CT skills.

\section{Critical Thinking and Web-Based Learning Environments}

Critical thinking is certainly an important skill to foster in students engaged in the learning process, for both their professional and personal prosperity (Noll \& Wilkins, 2003). An examination of the virtual learning environment literature does not however indicate consensus on how to foster this skill, nor with what modes of deliver, nor how demographics may mediate the outcomes. It is acknowledged that in the online environment, the challenge is even greater than in the traditional setting.

Constraints on the development of critical thinking in virtual environments seems more daunting than in the traditional classroom setting, due to the lack in the body of knowledge regarding the integration of creative instructional strategies, such as constructivist learning philosophies, active learning, team-based learning, and discussion using digital media. MacKnight, (2000) expressed an important pitfall in that "we fall prey to modern communication media, which present a world where the prepackaging of intellectual positions and views is so ingenious that thinking seems unnecessary." On the other hand, some researchers suggest online can actually help by giving students opportunities for mastery learning, removal of time-constraints for learning, self-paced learning, anonymous online discussion, etc. (Benson \& Samarawickrema, 2009). This complex context (critical thinking in virtual environments) (Saade, He and Kira, 2007) sets the backdrop for the study presented herein which surveys students' perceptions of the critical thinking skills they may have acquired and/or used via the resources and activities of an entirely online course.

\section{Methodology}

Davis (1989) has shown that system use is tied to user's perceptions, while Keengwe (2007) and Koohang \& Durante (2003) found that a relationship exists between students' personal computer proficiency and students' perceptions of the effect of computer technology to improve their learning. Song, et al. (2004) focused on students' perceptions as a way to improve online or distance learning. Perceptions are, therefore, important considerations when integrating technology into learning, especially virtual learning (Thomas and Morin, 2010). Consequently, the survey used in our study measures the subjective evaluation of the students' use and/or development of critical thinking while interacting with the course resources, activities and technologies 


\section{The Course}

This research investigates what observations could be made about students' acquisition of one aspect of higher-order learning, namely critical thinking, from the perspective of students' perceptions and performance in an undergraduate online introductory computer literacy course. In such a course, students are required to demonstrate acquisition of lower level skills, such as remembering concepts as well as keystrokes in software, and additionally, how to think critically about the problems which the software is being used to solve. Learning in the course is supported by various activities and resources, as well technology, as presented in Table 1, below. Some of those items can be classified as a learning activity, while others refer to the learning content. We also distinguished between static (tangible and digital) and interactive learning.

Table1. Characteristics of course components.

\begin{tabular}{|l|c|c|c|c|}
\hline & $\begin{array}{c}\text { Learning } \\
\text { Activity }\end{array}$ & $\begin{array}{c}\text { Learning } \\
\text { Content }\end{array}$ & Static & Interactive \\
\hline Activities & $\checkmark$ & & & $\checkmark$ \\
\hline Assignments & $\checkmark$ & & $\checkmark$ & \\
\hline Excel mini case (project) & $\checkmark$ & & $\checkmark$ & \\
\hline Access mini case (project) & $\checkmark$ & & & $\checkmark$ \\
\hline Quiz & $\checkmark$ & & & $\checkmark$ \\
\hline EISEL & & $\checkmark$ & $\checkmark$ & \\
\hline Resources & & $\checkmark$ & $\checkmark$ & \\
\hline Textbook & & $\checkmark$ & & $\checkmark$ \\
\hline Online book chapters & & $\checkmark$ & & $\checkmark$ \\
\hline Overall online system & & & \\
\hline Material on the Web & & & \\
\hline
\end{tabular}

\section{The Survey}

This course is offered completely online without any face-to-face interaction with the professor or the teaching assistants. At the end of the semester, students were asked to respond to an online survey as candidly as possible. The survey used in this study is based on an instrument developed by the third author (Thomas, 2001). Students were instructed that there were no right or wrong answers and that only their beliefs and perceptions about the course components and their experiences with the different tools for learning were requested.

\section{Discussion and Analysis of Results}

\section{Demographics and Definition Understanding}

There were a total of 985 students enrolled in the course and 490 of them completed the survey online for a response rate of $51.2 \%$. Of those who completed the survey, $44 \%$ were female students. Most respondents (73.3\%) were in the $20-23$ age group, $17.4 \%$ in the $24-30$ age group and $4 \%$ and $5.3 \%$ were in the below 20 and above 30 categories, respectively. The average age is 22.7 
years, while the median is 22 . We also note that approximately $86 \%$ of students claimed to have average to excellent understanding of the definition of critical thinking as proposed.

\section{Students 'Perceived Contribution of Activities and Resources}

In Table 2 below, descriptive statistics, and the distribution of students' perception of the contributions of activities/resources, to Critical Thinking Skills, in percentages are presented. This distribution provides us with a measure of the perceived relative influence of course elements (activities/resources) on the development of critical thinking skills. The Table also presents the Positive impact of each activities / resources defined as the total proportion of answers in the categories 'Moderate' and 'A lot'. The results in Table 2 clearly show that approximately $74 \%$ of the students bought the physical textbook and about half of them, $52 \%$, felt that its perceived contribution to critical thinking skills is moderate. Moreover, it is clearly evident that students felt the activities contributed more, compared to resources, to critical thinking. In terms of the strongest positive impact, Assignments are perceived as having contributed the most, followed by the Excel mini case project.

Table 2. Distribution of student perception (\%) of contribution to critical thinking skills.

\begin{tabular}{|l|c|c|c|c|c|c|c|}
\hline & N & $\begin{array}{c}\text { Mea } \\
\text { n }\end{array}$ & S.D. & $\begin{array}{c}\text { Not at } \\
\text { all } \\
(\%)\end{array}$ & $\begin{array}{c}\text { Moder- } \\
\text { ate } \\
(\%)\end{array}$ & $\begin{array}{c}\text { A lot }^{3} \\
(\%)\end{array}$ & $\begin{array}{c}\text { Positive Im- } \\
\text { pact (\%) }\end{array}$ \\
\hline Activities & 483 & 2.20 & 0.69 & 15.7 & 48.0 & 36.3 & 84.3 \\
\hline Assignments & 488 & 2.21 & 0.72 & 17.8 & 43.5 & 38.7 & 82.2 \\
\hline Excel mini case (project) & 483 & 2.18 & 0.70 & 18.6 & 45.1 & 36.3 & 81.4 \\
\hline $\begin{array}{l}\text { Access mini case (pro- } \\
\text { ject) }\end{array}$ & 488 & 2.18 & 0.73 & 19.3 & 43.6 & 37.1 & 80.7 \\
\hline Quiz & 486 & 2.13 & 0.72 & 20.6 & 46.3 & 33.1 & 79.4 \\
\hline EISEL & 361 & 1.95 & 0.69 & 26.6 & 52.1 & 21.3 & 73.4 \\
\hline Resources & 485 & 1.90 & 0.67 & 28.0 & 54.0 & 17.9 & 71.9 \\
\hline Textbook & 485 & 2.07 & 0.70 & 21.2 & 50.9 & 27.8 & 78.7 \\
\hline Online book chapters & 489 & 2.10 & 0.68 & 18.6 & 52.6 & 28.8 & 81.4 \\
\hline Overall online system & & & & & \\
\hline Material on the Web & & & & & \\
\hline
\end{tabular}

An overall ANOVA and Tukey-Kramer analysis were performed and it was found that students view the contributions of the 'Textbook 'and the 'Online Book' as significantly less than all activities in the course. The resource contributing the most to critical thinking skills was perceived to be "Material on the Web".

\section{Conclusions}

Results clearly indicate that the relationship between students' perception of learning activities and critical thinking is stronger than that with resources. More specifically, interactive components, regardless of their nature (learning activity / resources), were perceived to contribute to CT 
more than other identified types such as static content, assessment and project-based. Putting everything together, it seems that the world of books for learning is fading away. Our experience, and our attempt in this study to quantify the relative importance of books, whether if they exist in physical or digital form, indicates that for any content to be perceived as contributing to thinking it must be presented in an interactive mode. When it comes to critical thinking, interactivity was shown to rank at the level of assignments (actually slightly higher), to solve a business problem using software (EXCEL and ACCESS) as a tool.

From a practical perspective, designers and teachers of online courses have one primary goal, which is to enhance the student's learning experience - this includes learning and behavior. Critical thinking skills are important for the careers for which students are being prepared, in an area in which obsolescence is an ongoing threat in the digital world, given the speed at which technology changes. Without these skills and the ability to adapt to new innovations in technology, the student will be severely disadvantaged. More research is therefore needed to better understand the relationship between course activities, resources and technologies employed, and their impact on critical thinking development.

\section{References}

Benson, R., \& Samarawickrema, G. (2009). Addressing the context of e-learning: Using transactional distance theory to inform design. Distance Education, 30, 5-21.

Davis, F.D. (1989). Perceived usefulness, perceived ease of use, and user acceptance in information technology. MIS Quarterly, 13(3), 319-340.

Follman, J., Lavely, C., \& Berger, N. (1997). Inventory of instruments of critical thinking. Informal Logic, $18(2 \& 3), 261-267$.

Johnson, T. E., Archibald, T. N., \& Tenenbaum, G. (2010). Individual and team annotation effects on students' reading comprehension, critical thinking, and meta-cognitive skills. Computers in Human Behavior, 26, 1496-1507.

Keengwe, J. (2007). Faculty integration of technology into instruction and students' perceptions of computer technology to improve student learning. Journal of Information Technology Education, 6, 169180.

Koohang, A., \& Durante, A. (2003). Learners' perceptions toward the web-based distance learning activities/assignments portion of an undergraduate hybrid instructional model. Journal of Information Technology Education, 2, 105-113.

MacKnight, C. B. (2000) Teaching critically about critical thinking through online discussions. EDUCAUSE Quarterly, 4, 38-41.

Mandernach, B. J. (2006). Thinking critically about critical thinking: Integrating online tools to promote critical thinking. Critical Thinking - Insight: A Collection of Faculty Scholarship, 1, 41-50.

Noll, C. L., \& Wilkins, M. (2002). Critical skills of IS professionals: A model for curriculum development. Journal of Information Technology Education, 1(3), 144-154.

Saadé, G. R., He, X., \& Kira, D. (2007). Exploring dimensions to online learning. Computers in Human Behavior, 23, 1721-1739.

Song, L., Singleton, E. S., Hill, J. R., \& Koh, M. H. (2004). Improving online learning: Student perceptions of useful and challenging characteristics. Internet \& Higher Education, 7(1), 59-70.

Thomas, J. D. E. (2001). Technology integration and higher-order learning. Proceedings of Conference in Advanced Technology in Education Conference, Banff, Calgary, Canada, May.

Thomas, J. D. E. \& Morin, D. (2010). Technological supports for onsite and distance education and students' perceptions of acquisition of thinking and team-building skills, International Journal of Distance Education Technologies, 8(2), 1-13. 
Yang, C. Y. (2008). A catalyst for teaching critical thinking in a large university class in Taiwan: asynchronous online discussions with the facilitation of teaching assistants. Educational Technology Research and Development, 56, 241-264.

\section{Biographies}

Dr. Danielle Morin is a Professor at the John Molson School of Business at Concordia Univer-

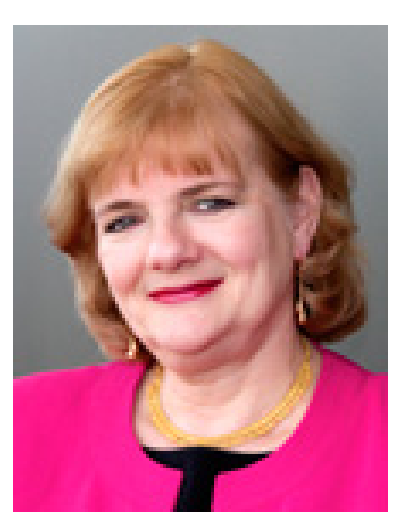
sity, Montreal, Canada. She received a BSc in Mathematics and MSc Statistics from Université de Montréal, and a PhD in Statistics from McGill University. Her major academic interests are business statistics and multivariate statistics, which she has taught in both graduate and undergraduate programs. Her current research interests are focused on university education, namely the impact on technology integration and interdisciplinary on student's learning and acquisition of higher order skills. Over the years, Dr Morin has held several senior administrative positions at Concordia University. In 2005, she was awarded the YWCA Women of Excellence Award in the Education Category as well as the Concordia Alumni Recognition Award for teaching excellence.

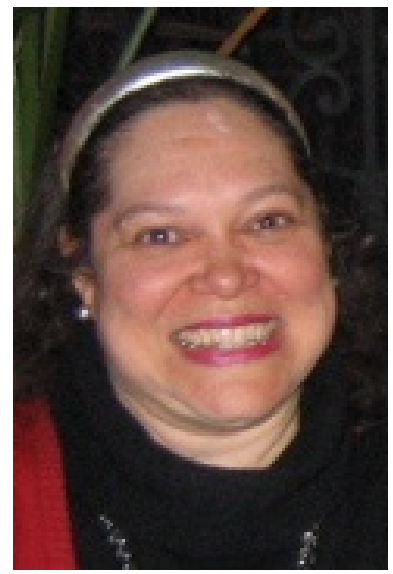

Jennifer D.E. Thomas is Professor of Information Systems at Pace University in New York City in the Seidenberg School of Computer Science and Information Systems. She received her Ph.D. and M.B.A. from Concordia University in Montreal, Canada, and her Bachelor of Commerce from McGill University, Montreal, Canada. Her research interests include Knowledge Management, User Experience - Human Factors, Human-Computer Interaction, Multimedia, and the Impact of Technology Integration on Learning. She teaches onsite and online courses at both the graduate and undergraduate levels - Introduction to Information Systems Concepts, User Experience - Multimedia and Human Computer Interaction, Business Telecommunications, Distributed Computing, and Research Methodology. She also previously cotaught an undergraduate Beowulf and Multimedia course with the English Department.

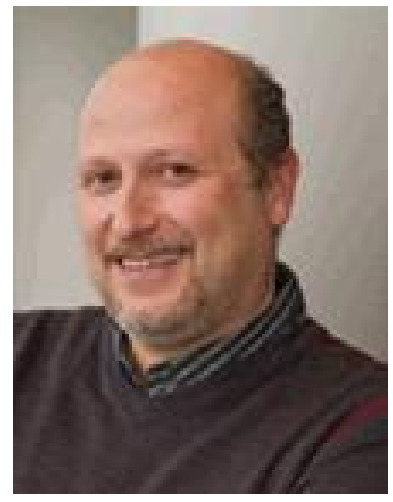

Dr. Raafat George Saadé has been teaching in the faculty since 1998. He obtained his Ph.D. in 1995 (Concordia University) after which he received the Canadian National Research Council postdoctoral fellowship, which he completed at McGill University in Montreal. Dr. Saade has published in journals such as Information \& Management, Decision Sciences, and Expert Systems with Applications. His research interests include the development and assessment of information systems, and the supply chain of digital information products. 